\title{
Use of Aluminosilicate Residue from Insulators of High Voltage Transformers for the Adsorption of Basic Dyes
}

\author{
Fernando C. G. Murga, ${ }^{a}$ José D. R. de Campos $^{a}$ and Roberta Signini ${ }^{\circledR} * a$ \\ ${ }^{a}$ Universidade Estadual de Goiás, Campus Central, CP 459, 75001-970 Anápolis-GO, Brazil
}

\begin{abstract}
In this study, an aluminosilicate residue from insulators of high voltage transformers was used for the adsorption of basic dyes. The absorbent was characterized by X-ray fluorescence analysis, X-ray diffraction analysis, scanning electron microscopy, multimolecular adsorption theory (Branauer-Emmet-Teller (BET)) and determination of the point of zero charge $\left(\mathrm{pH}_{\mathrm{PZC}}\right)$. The effect of solution $\mathrm{pH}$ and adsorbent mass, the kinetic and thermodynamic behavior at different temperatures and the application of non-linear isotherm models of Langmuir, Freundlich, Temkin and Dubinin-Radushevich were investigated. The $\mathrm{pH}_{\mathrm{PZC}}$ value for the aluminosilicate was 3.7. The best conditions for adsorption of methylene blue and crystal violet dyes were $\mathrm{pH} 8.0$ and adsorbent mass of $1100 \mathrm{mg}$ in $25 \mathrm{~mL}$. The best fit for the experimental data was obtained applying the pseudo-second-order kinetic model, with an equilibrium time of 480 to $720 \mathrm{~min}$, and the activation energy suggests a physical adsorption mechanism. Isothermal parameters suggest a heterogeneous, favorable and predominantly physical surface adsorption. The thermodynamic studies indicated that the adsorption process is not spontaneous and is exothermic and the Gibbs energy values $\left(\Delta \mathrm{G}^{\mathrm{o}}\right)$ suggest physisorption.
\end{abstract}

Keywords: aluminosilicate residue, basic dyes, adsorption

\section{Introduction}

The textile industry is one of the biggest consumers of dyes, which are used in the production stages, and thus the control and treatment of the effluents generated are required, since they have a high toxic organic load. The degradation of aquatic environments is strongly related to an increase in the organic load provided by these industrial dyes. ${ }^{1}$ Environmental changes due to dyes discarded without proper treatment disrupt the natural dynamics of biological communities, with negative impacts being associated with the $\mathrm{pH}$, turbidity, chemical and biological oxygen demand, the amount of total solids in suspension and other physicochemical parameters of the hydric body. ${ }^{2-4}$ Many techniques can be used to remove dyes from effluents, including oxidation, ${ }^{5}$ photocatalytic degradation, ${ }^{3,6,7}$ adsorption ${ }^{8}$ and others. ${ }^{3,9}$ Adsorption is of particular interest due to the fact that trace elements can be removed and the adsorbent can be recovered. The effectiveness of effluent treatments applying an adsorption process is related to the adsorbent, the adsorbate and the medium of diluted solutions. In general, adsorption processes are more versatile and

*e-mail: roberta.signini@ueg.br superior to other techniques for wastewater treatment in terms of initial cost, simplicity of design, ease of operation, sensitivity to toxic substances and removal of dyes even from dilute solutions. ${ }^{10} \mathrm{~A}$ wide variety of adsorbents are available for this purpose, such as activated carbon, ${ }^{11-14}$ carbonized watermelon rind, ${ }^{15}$ coconut shell, ${ }^{16}$ clays, ${ }^{10,17,18}$ silicas, ${ }^{19,20}$ chitosan, ${ }^{21}$ chitosan-activated charcoal composite, ${ }^{22,23}$ and chitosan-epichlorohydrin/zeolite, ${ }^{24}$ and these can be reused in the process several times.

Companies that supply electricity generate residues of ceramic material from electrical insulators, through equipment maintenance and modernization processes, and these accumulated over time. The characteristics of this material differ from those of traditional ceramics. Its basic composition consists of kaolin, clay, quartz and potassic feldspar, ${ }^{25}$ and it is referred to by the generic name of white ceramic. Chemically, it is composed of hydrated aluminum silicates $\left(\mathrm{xSiO}_{2} / \mathrm{yAl}_{2} \mathrm{O}_{3}\right)$ and iron, along with a limited number of minerals comprised of alkaline and alkaline earth elements called aluminosilicates..$^{26,27}$ The adsorbent structure can lead to greater adsorption efficiency and ion exchange capacity than the conventional methods for such treatments ${ }^{17}$ and this material is suitable for use as a catalyst. ${ }^{25,28}$ 
Investigations into the adsorption mechanisms of clay minerals, as well as their derivatives and residues, are of interest for the treatment of wastewater, due to their lowcost, abundance in nature, wide availability locally, low sensitivity to toxic substances, cation exchange capacity and high chemical stability. ${ }^{10}$ The modification of clays and residues can increase the processing cost, but treatments applying these residues to remove organic and inorganic dyes from effluent can be viable and highly reliable. ${ }^{10,29}$ The effectiveness of ceramic residues as adsorption agents for basic dyes is associated with the chemical and structural composition of the adsorbent ${ }^{30}$ and the removal of cationic dyes by natural clay is strongly dependent on the process temperature, initial dye concentration and $\mathrm{pH}$ of the solution. ${ }^{31}$

In this study, the use of waste material as an adsorbent was investigated through its application in the treatment of diluted aqueous solutions of dyes used at textile plants. The residue from insulators of high voltage transformers (aluminosilicate) was subjected to $\mathrm{ASTM}^{32,33}$ tests to ensure that the chemical composition and physicochemical properties of the waste of electrical insulators are constant and reproducible. The material was used in adsorption experiments to investigate the ion exchange with dyes present in wastewater from textile plants, such as methylene blue and crystal violet. The samples were characterized by vibrational spectroscopy in the infrared region with Fourier transform (FTIR), X-ray diffraction (XRD), scanning electron microscopy (SEM), X-ray fluorescence (XRF) and Branauer-Emmet-Teller (BET) multimolecular adsorption analysis in $\mathrm{N}_{2}$ atmosphere and the point of zero charge (PZC) was determined. Physicochemical parameters were also investigated through studies on the kinetics, adsorption isotherms, $\mathrm{pH}$, adsorbent dosage and thermodynamics.

\section{Experimental}

\section{Materials}

The aluminosilicate (ALMS) residue from high voltage transformers was obtained from the company Enel. The material was cleaned to remove visible residues, crushed in mills up to a suitable granulometric size, separated using sieves of 80 to 150 mesh, and packaged in hermetically-sealed polyethylene vials, in different granulometries, in a clean dry environment. Methylene blue (MB) and crystal violet (CV) dyes were purchased from Sigma-Aldrich (St. Louis, USA). Hydrochloric acid $(\mathrm{HCl})$, sodium hydrate $(\mathrm{NaOH})$ and all the other compounds were obtained as analytical reagents from Sigma-Aldrich (St. Louis, USA).

\section{Characterization of the aluminosilicate residue}

The FTIR spectroscopy study of ALMS and ALMS/dyes was performed on a PerkinElmer Frontier spectrophotometer, Model FT-IR/NIR (Waltham, USA). The chemical analysis was performed by X-ray fluorescence spectrometry (XRF), using a Thermo spectrometer by Malvern Panalytical, model Claisse M4 Fusion (Malvern Hills, UK), with a power of $4.2 \mathrm{KV}$, according to the ISO 29581-2. ${ }^{33}$ The average pore diameter (D), specific surface area $(\mathrm{S})$ and pore volume $(\mathrm{Vp})$ were obtained from $\mathrm{N}_{2}$ adsorption measurements taken on an automatic physisorption analyzer model ASAP 2020 by Micromeritics Instrument Corp., (Norcross, GA, USA). The morphology was analyzed by scanning electron microscopy (SEM) on a Jeol Ltd., model JSM-IT300 microscope, with an electron acceleration voltage of $7 \mathrm{kV}$ (Akishima, Japan). X-ray diffraction (XRD) patterns of the powdered samples were collected on an Oxford diffractometer, model 51-ADD0048 (Yarnton, UK) ( $\lambda=1.54 \AA$ ), in the range of $10-80^{\circ}$, using a continuous scan with a velocity of $0.05^{\circ} \mathrm{min}^{-1}$.

\section{Study on the $\mathrm{pH}_{\mathrm{pzc}}$}

To determine the point of zero charge (PZC), $20 \mathrm{~mL}$ of $0.1 \mathrm{~mol} \mathrm{~L}^{-1} \mathrm{NaCl}$ at different $\mathrm{pH}$ values (1-11) was added to $20 \mathrm{mg}$ of the adsorbent. The samples were shaken at $100 \mathrm{rpm}$ for $24 \mathrm{~h}$ at $298 \mathrm{~K}$, after which time the solutions were filtered and the final $\mathrm{pH}$ was measured. To determine the $\mathrm{pH}_{\mathrm{pzc}}$, a graph of the final $\mathrm{pH}$ as a function of the initial $\mathrm{pH}$ was constructed, where $\mathrm{pH}_{\mathrm{pzc}}$ is the point at which the difference between final $\mathrm{pH}-$ initial $\mathrm{pH}=0$.

\section{Adsorption experiments}

The concentrations of the dyes before and after the equilibrium were determined on a PerkinElmer UV-Vis spectrophotometer, model Lambda 25 (Waltham, USA) at wavelengths of 665 and $589 \mathrm{~cm}^{-1}$ for methylene blue (MB) and crystal violet (CV), respectively. The adsorption studies were carried out in triplicate. The dye removal (\%) and adsorption capacity $\left(\mathrm{q}_{\mathrm{e}}\right)$ were calculated as follows:

$$
\begin{aligned}
& \operatorname{removal}(\%)=\frac{\mathrm{C}_{0}-\mathrm{C}_{\mathrm{eq}}}{\mathrm{C}_{0}} \times 100 \\
& \mathrm{q}_{\mathrm{e}}=\frac{\left(\mathrm{C}_{0}-\mathrm{C}_{\text {eq }}\right) \times \mathrm{V}}{\mathrm{m}}
\end{aligned}
$$

where $\mathrm{C}_{0}$ and $\mathrm{C}_{\mathrm{eq}}$ are, respectively, the concentrations (in $\mathrm{mg} \mathrm{L}^{-1}$ ) of the dyes in the aqueous phase before and after 
$\left(\mathrm{C}_{\mathrm{eq}}\right)$ the equilibration, $\mathrm{q}_{\mathrm{e}}$ is the equilibrium adsorption capacity $\left(\mathrm{mg} \mathrm{g}^{-1}\right), \mathrm{m}$ is the adsorbent mass $(\mathrm{g})$ and $\mathrm{V}$ is the solution volume $(\mathrm{L})$.

For the $\mathrm{pH}$ studies, $100 \mathrm{mg}$ of adsorbent were added to $25 \mathrm{~mL}$ of the dye solution with a concentration of $10 \mathrm{mg} \mathrm{L}^{-1}$ and the suspensions were kept under stirring (110 rpm) for $24 \mathrm{~h}$ at $298 \mathrm{~K}$. Solutions of $\mathrm{HCl}$ and $\mathrm{NaOH}\left(0.1 \mathrm{~mol} \mathrm{~L}^{-1}\right)$ were used to adjust the initial $\mathrm{pH}$. For the effect of the mass on the adsorption process, $25 \mathrm{~mL}$ of the dye solution at a concentration of $10 \mathrm{mg} \mathrm{L}^{-1}$ were used, at the optimum $\mathrm{pH}$, and the suspension was kept under stirring for $24 \mathrm{~h}$ at $298 \mathrm{~K}$. The mass of the adsorbent varied from 200 to $1500 \mathrm{mg}$.

The experiments to investigate the adsorption kinetics were carried out at 298, 308 and $318 \mathrm{~K}$ with dyes concentration of $10 \mathrm{mg} \mathrm{L}^{-1}$ and adsorbent mass of $1100 \mathrm{mg}$, at optimum $\mathrm{pH}$. The kinetics were studied using the pseudo first order (equation 3), ${ }^{29,34,35}$ pseudo second order (equation 4), ${ }^{29,36-38}$ intraparticle diffusion ${ }^{29}$ (equation 5) and Elovich $^{39,40}$ (equation 6) models.

$\log \left(\mathrm{q}_{\mathrm{e}}-\mathrm{q}_{\mathrm{t}}\right)=\log \mathrm{q}-\frac{\mathrm{k}_{1}}{2.303} \mathrm{t}$

$\frac{\mathrm{t}}{\mathrm{q}_{\mathrm{t}}}=\frac{1}{\mathrm{k}_{2} \mathrm{q}_{\mathrm{e}}^{2}}+\frac{1}{\mathrm{q}_{\mathrm{e}}} \mathrm{t}$

$\mathrm{q}_{\mathrm{t}}=\mathrm{k}_{\mathrm{d}}(\mathrm{t})^{1 / 2}$

$\mathrm{q}_{\mathrm{t}}=\frac{1}{\beta} \ln (\alpha \beta)+\frac{1}{\beta} \ln \mathrm{t}$

where $\mathrm{q}_{\mathrm{t}}\left(\mathrm{mg} \mathrm{g}^{-1}\right)$ is the quantity adsorbed at time $\mathrm{t}, \mathrm{q}_{\mathrm{e}}$ $\left(\mathrm{mg} \mathrm{g}^{-1}\right)$ is the quantity adsorbed at equilibrium and $\mathrm{k}_{1}$ $\left(\mathrm{min}^{-1}\right)$ and $\mathrm{k}_{2}\left(\mathrm{~g} \mathrm{mg}^{-1} \mathrm{~min}^{-1}\right)$ and $\mathrm{k}_{\mathrm{d}}$ are the pseudo-firstorder, pseudo-second-order and diffusion kinetics rate constants, respectively, and $\alpha$ and $\beta$ are the Elovich model parameters.

The isothermal adsorption experiments were conducted at 298,308 and $318 \mathrm{~K}$ at optimum $\mathrm{pH}$ for $24 \mathrm{~h}$. The concentrations of the dye solutions ranged from 0.625 to $20 \mathrm{mg} \mathrm{L}^{-1}$, the adsorbent mass was $1100 \mathrm{mg}$, and the time was that required to reach equilibrium. The correlation of the equilibrium adsorption parameters was analyzed applying the following non-linear isotherm models: Langmuir, Freundlich, Temkin and Dubinin-Radushkevich (D-R).

The Langmuir isotherm model considers a mechanism of physical adsorption and non linearity, and is obtained through the general formula: ${ }^{29,41}$

$\mathrm{q}_{\mathrm{e}}=\frac{\mathrm{q}_{\max } \times \mathrm{K}_{\mathrm{L}} \times \mathrm{C}_{\mathrm{eq}}}{1+\mathrm{K}_{\mathrm{L}} \times \mathrm{C}_{\mathrm{eq}}}$ where $\mathrm{q}_{\mathrm{e}}$ is the concentration of dye adsorbed by the adsorbent in $\mathrm{mg} \mathrm{g}^{-1}, \mathrm{C}_{\mathrm{eq}}$ the final concentration of the dye in solution, $\mathrm{q}_{\max }$ the maximum adsorption capacity in $\mathrm{mg} \mathrm{g}^{-1}$ and $\mathrm{K}_{\mathrm{L}}\left(\mathrm{L} \mathrm{mg}^{-1}\right)$ the Langmuir constant. ${ }^{42-44}$

The $R_{L}$ parameter is an adimensional constant, called the equilibrium parameter, and it represents the degree of adsorption of the system. This parameter is calculated through the Langmüir isotherm model, and is defined by equation $8 .{ }^{41,42,45}$

$\mathrm{R}_{\mathrm{L}}=\frac{1}{1+\mathrm{K}_{\mathrm{L}} \times \mathrm{C}_{0}}$

The value of the $R_{L}$ parameter indicates whether the process is favorable or unfavorable. ${ }^{29,42,43}$ Values of $\mathrm{R}_{\mathrm{L}}$ greater than 1 indicate that the isothermal process is unfavorable, $R_{L}$ equals 1 indicates that the isotherm is linear, $R_{L}$ values between 0 and 1 indicate that the process is favorable, and when $R_{L}$ equals zero the process is irreversible. ${ }^{42,44}$

In the case of the Freundlich isotherm model, it is considered that the adsorption of the molecules of the adsorbate occurs in multilayers on the adsorbent surface. ${ }^{46-48}$ Its parameters obtained by the construction of an adsorption isotherm indicate the heterogeneity of the adsorbent surface or the adsorption intensity in the system. ${ }^{47-49}$ The non linearized form was given by the formula below.

$\mathrm{q}_{\mathrm{e}}=\mathrm{K}_{\mathrm{F}} \times \mathrm{C}_{\mathrm{eq}}^{1 / \mathrm{n}}$

The $\mathrm{K}_{\mathrm{F}}$ parameter is the Freundlich constant for the system ${ }^{43,44} \mathrm{q}_{\mathrm{e}}$ is the amount of dye adsorbed in the equilibrium state, $\mathrm{C}_{\mathrm{eq}}$ is the final concentration of the solution. The empirical parameter $1 / \mathrm{n}$ measures the adsorption intensity or the heterogeneity of the surface, varying from 0 to 1 . The closer the value is to 0 the greater the heterogeneity of the solid surface will be. ${ }^{48-50}$ The Freundlich parameter $\mathrm{n}$ indicates the degree of nonlinearity between the initial concentration, the equilibrium concentration, and the maximum adsorption capacity of the system. ${ }^{47}$ Values equal to 1 indicate that the adsorption process is linear while values lower than 1 indicate that the adsorption process is chemical and favorable for the entire concentration range studied. Values greater than 1 indicate that the process is physical and favorable for a higher concentration range, but unfavorable for lower

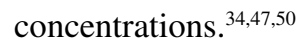

Proposed in 1940, the Temkin isotherm model is based on assessing the indirect interactions that occur between adsorbent and adsorbate. The nonlinear form of the Temkin ${ }^{51}$ and Pyzhev model is expressed as: 
$\mathrm{q}_{\mathrm{e}}=\mathrm{B}_{\mathrm{T}} \ln \left(\mathrm{K}_{\mathrm{T}} \mathrm{C}_{\mathrm{eq}}\right)$

where $\mathrm{K}_{\mathrm{T}}$ is the Temkin isotherm constant $\left(\mathrm{L} \mathrm{g}^{-1}\right), \mathrm{B}_{\mathrm{T}}=\mathrm{RT} / \mathrm{b}$, $\mathrm{b}$ is the Temkin ${ }^{51}$ constant related to the heat of sorption $\left(\mathrm{J} \mathrm{mol}^{-1}\right), \mathrm{T}$ is the absolute temperature $(\mathrm{K})$ and $\mathrm{R}$ is the ideal gas constant $\left(8.314 \mathrm{~J} \mathrm{~mol}^{-1} \mathrm{~K}^{-1}\right)$.

The nature of the adsorption (i.e., chemical or physical) can be determined from the Dubinin-Radushkevich (D-R) isotherm. ${ }^{52,53}$ The nonlinear form of the DubininRadushkevich (D-R) isotherm is:

$\mathrm{q}_{\mathrm{e}}=\mathrm{q}_{\mathrm{m}} \mathrm{e}^{-\mathrm{B} \varepsilon^{2}}$

where $B$ is the sorption energy constant $\left(\mathrm{mol}^{2} \mathrm{~J}^{-2}\right), \mathrm{q}_{\mathrm{m}}$ is the theoretical monolayer sorption capacity $\left(\mathrm{mol} \mathrm{g}^{-1}\right)$, and $\varepsilon$ is Polanyi potential, which is given as:

$\varepsilon=\mathrm{RT} \ln \left(1+1 / \mathrm{C}_{\mathrm{e}}\right)$

where $\mathrm{R}$ is the ideal gas constant $\left(8.314 \mathrm{~J} \mathrm{~mol}^{-1} \mathrm{~K}^{-1}\right)$ and $\mathrm{T}$ is the solution temperature $(\mathrm{K}) .^{44}$ The value of the mean sorption energy, ${ }^{52} \mathrm{E}\left(\mathrm{kJ} \mathrm{mol}^{-1}\right)$, is expressed as:

$E=\frac{1}{\sqrt{(2 B)}}$

The value of this parameter indicates the most likely type of adsorption mechanism occurring: $1<\mathrm{E}<8 \mathrm{~kJ} \mathrm{~mol}^{-1}$ is related to physical adsorption and $8<\mathrm{E}<16 \mathrm{~kJ} \mathrm{~mol}^{-1}$ is associated with a chemical adsorption process (ionexchange).$^{46}$

Additionally, the effect of temperature was evaluated with the dye solutions at 298, 308 and $318 \mathrm{~K}$. In this procedure, $1100 \mathrm{mg}$ of adsorbent was placed in a glass bottle containing $50 \mathrm{~mL}$ of $10 \mathrm{mg} \mathrm{L}^{-1}$ dyes solutions, for the time required to reach equilibrium. Performing the adsorption study at different temperatures allows the thermodynamic parameters, that is, the variations in the Gibbs energy $\left(\Delta \mathrm{G}^{\mathrm{o}}\right)$, entropy $\left(\Delta \mathrm{S}^{\mathrm{o}}\right)$ and enthalpy $\left(\Delta \mathrm{H}^{\mathrm{o}}\right)$, to be determined. These parameters can be calculated using the following equations: ${ }^{29,43-45}$

$$
\begin{aligned}
& \ln \mathrm{K}_{\mathrm{d}}=\frac{\Delta \mathrm{S}^{\circ}}{\mathrm{R}}-\frac{\Delta \mathrm{H}^{\circ}}{\mathrm{RT}} \\
& \mathrm{K}_{\mathrm{d}}=\frac{\left(\mathrm{C}_{0}-\mathrm{C}_{\mathrm{eq}}\right)}{\mathrm{C}_{\mathrm{eq}}} \frac{\mathrm{V}}{\mathrm{m}} \\
& \Delta \mathrm{G}^{\circ}=\Delta \mathrm{H}^{\circ}-\mathrm{T} \Delta \mathrm{S}^{\circ}
\end{aligned}
$$

where $K_{d}$ is the partition coefficient in $\left(\mathrm{mL} \mathrm{mg}^{-1}\right)$, $R$ is the universal gas constant $\left(8.314 \mathrm{~J} \mathrm{~mol}^{-1} \mathrm{~K}^{-1}\right), \mathrm{T}$ is the absolute temperature $(\mathrm{K}), \mathrm{C}_{0}$ is the initial concentration, $\mathrm{C}_{\mathrm{eq}}$ is the equilibrium concentration, $\mathrm{V}$ is the volume (in $\mathrm{L}$ ) and $\mathrm{m}$ is the mass (in mg). ${ }^{43,44}$

\section{Results and Discussion}

\section{Characterization}

The FTIR spectra for the aluminosilicate and aluminosilicate with dyes were found to be similar (Figure 1), suggesting that the mass of dye retained in the adsorbent is very small (predominantly on the surface). The spectra indicate the presence of bond $(\mathrm{Si}-\mathrm{O})$ stretching of the accompanying minerals ${ }^{17}$ at $795 \mathrm{~cm}^{-1}$, silica bands characteristic of the quartz $(\mathrm{Si}-\mathrm{O}-\mathrm{Si})$ of siloxane groups linked to vicinal silanols ${ }^{18,29,31}$ at $1079 \mathrm{~cm}^{-1}$, a C-N bond stretching band at $1211 \mathrm{~cm}^{-1}$ typical of aliphatic and aromatic amines, ${ }^{29,31}$ and weak absorption at 639 to $666 \mathrm{~cm}^{-1}$ with a doublet signal, indicating the presence of aromatic rings $(\mathrm{R}-\mathrm{Ar})$ originating from the dye. ${ }^{29,31}$

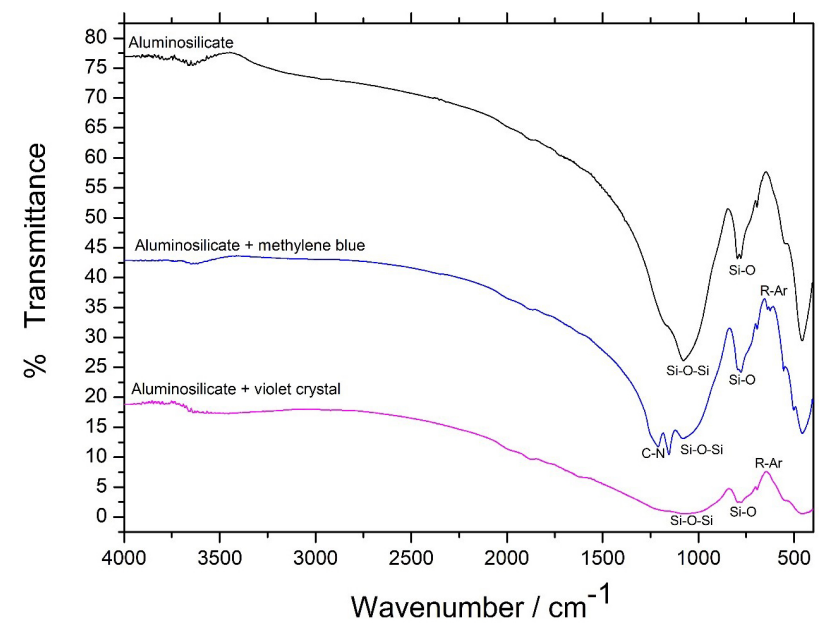

Figure 1. FTIR spectra of ALMS and ALMS after adsorption of MB and $\mathrm{CV}$ dyes.

The X-ray fluorescence spectrometry (XRF) results were used to quantified the contents of the following oxides: $\mathrm{SiO}_{2}, \mathrm{Fe}_{2} \mathrm{O}_{3}, \mathrm{Al}_{2} \mathrm{O}_{3}, \mathrm{Mn}_{2} \mathrm{O}_{3}, \mathrm{CaO}, \mathrm{MgO}, \mathrm{SO}_{3}, \mathrm{P}_{2} \mathrm{O}_{5}$, $\mathrm{Na}_{2} \mathrm{O}$ and $\mathrm{K}_{2} \mathrm{O}$ (Table 1 ). The main compounds found in the adsorbent were silicon dioxide $\left(\mathrm{SiO}_{2}\right)$, aluminum oxide $\left(\mathrm{Al}_{2} \mathrm{O}_{3}\right)$, sodium oxides and potassium oxide, indicating that the structure of the material provides, primarily, the exchange of $\mathrm{K}^{+}$and $\mathrm{Na}^{+}$cations (Table 1 ). The adsorbent material presented an $\mathrm{Si} / \mathrm{Al}$ ratio of 4.2 (m:m), suggesting that it has the characteristics of an acid adsorbent, ${ }^{30}$ functioning as a Bronsted-Lowry acid. Acid adsorbents are recommended for the removal of cationic dyes such as methylene blue and crystal violet. ${ }^{28,29}$ 
Table 1. The chemical analysis of the adsorbent

\begin{tabular}{lccccccccccc}
\hline Element & $\mathrm{SiO}_{2}$ & $\mathrm{Fe}_{2} \mathrm{O}_{3}$ & $\mathrm{Al}_{2} \mathrm{O}_{3}$ & $\mathrm{Mn}_{2} \mathrm{O}_{3}$ & $\mathrm{TiO}_{2}$ & $\mathrm{CaO}$ & $\mathrm{MgO}$ & $\mathrm{SO}_{3}$ & $\mathrm{P}_{2} \mathrm{O}_{5}$ & $\mathrm{Na}_{2} \mathrm{O}$ & $\mathrm{K}_{2} \mathrm{O}$ \\
\hline Content $/ \%$ & 72.3 & 1.26 & 17.1 & 0.02 & 0.51 & 0.86 & 1.2 & 0.00 & 0.05 & 1.20 & 4.2 \\
\hline
\end{tabular}

The morphology of the ALMS sample is shown in Figure 2 where it can be observed that it has rough and striated irregular surface and a non-porous appearance. Based on the measurement results for the specific surface area $(\mathrm{S})$, pore volume $(\mathrm{Vp})$ (Table 2) and average pore diameter (D), and the BET spectra shown in Figure 3, the adsorbent was characterized as a non-porous material, suggesting that adsorption occurred predominantly on the surface of the material (Table 2). Although aluminosilicate has a low surface area compared to activated carbon (neutral material), it has a greater surface charge, provides ion

Table 2. Physicochemical properties of the adsorbent

\begin{tabular}{lccc}
\hline Property & $\mathrm{S} /\left(\mathrm{m}^{2} \mathrm{~g}^{-1}\right)$ & $\mathrm{Vp} /\left(\mathrm{cm}^{3} \mathrm{~g}^{-1}\right)$ & $\mathrm{D} / \mathrm{nm}$ \\
\hline Adsorbent & 0.3396 & $1.52 \times 10^{1}$ & 12.1972 \\
\hline
\end{tabular}

S: specific surface area; Vp: pore volume; D: average pore diameter.

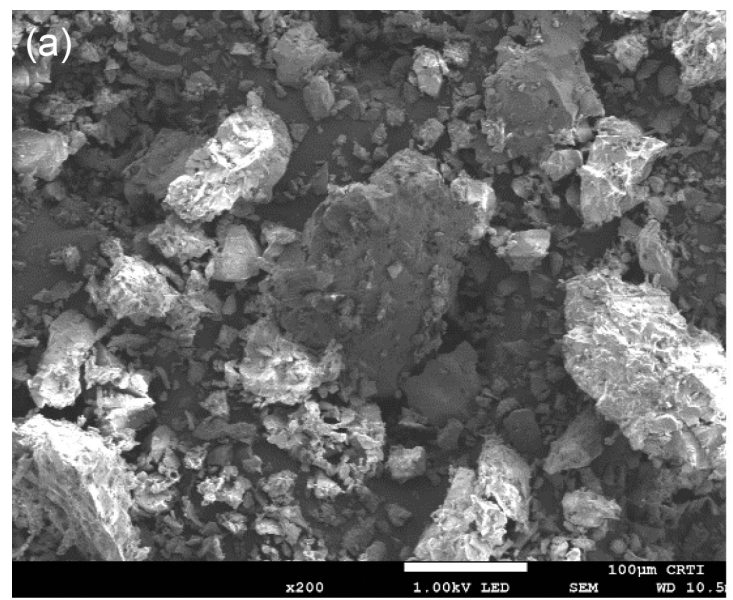

Figure 2. SEM micrographs of the adsorbent: (a) 200x and (b) 5000x.

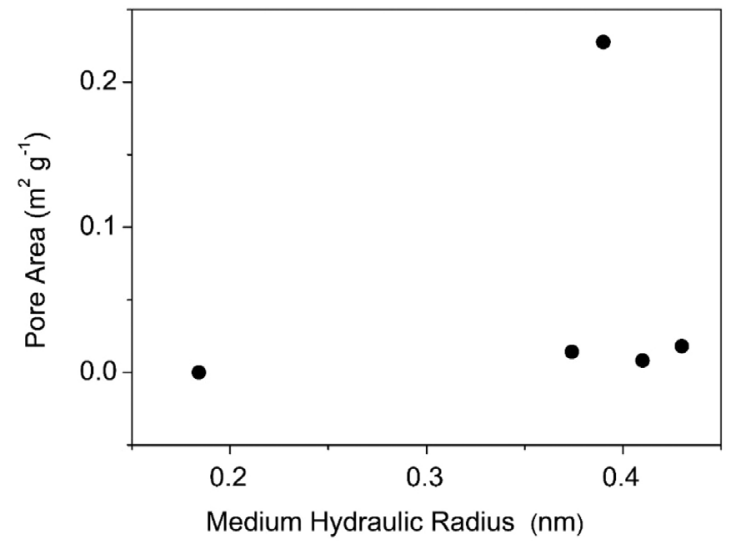

Figure 3. BET results for the surface area. exchange at low cost, is easy to regenerate and represents an efficient alternative for wastewater treatment. In this study, cationic dyes were used, to ensure a greater influence from the surface charge than the large surface area.

X-ray diffraction patterns provide three basic types of information: the position of the peaks are characteristic of certain materials; the intensity of the peaks are associated with the chemical composition and the location of atoms in unit cells; and the shape of the peaks is related to the quality of the crystals. ${ }^{54}$ The diffractogram for the adsorbent (Figure 4a) had peaks (20) at 20.85, 26.60 and $26.65^{\circ}$, indicating the presence of the crystalline phase of silica $\left(\mathrm{SiO}_{2}\right)$ within the aluminosilicate, ${ }^{29}$ a member of the quartz family, thus identifying a partially-organized crystalline or semi-crystalline material. This analysis is based on the large amount of $\mathrm{SiO}_{2}$ found in the XRF analysis of the adsorbent. The peaks at $20.80,20.90,26.65$ and $26.85^{\circ}$ in the reference
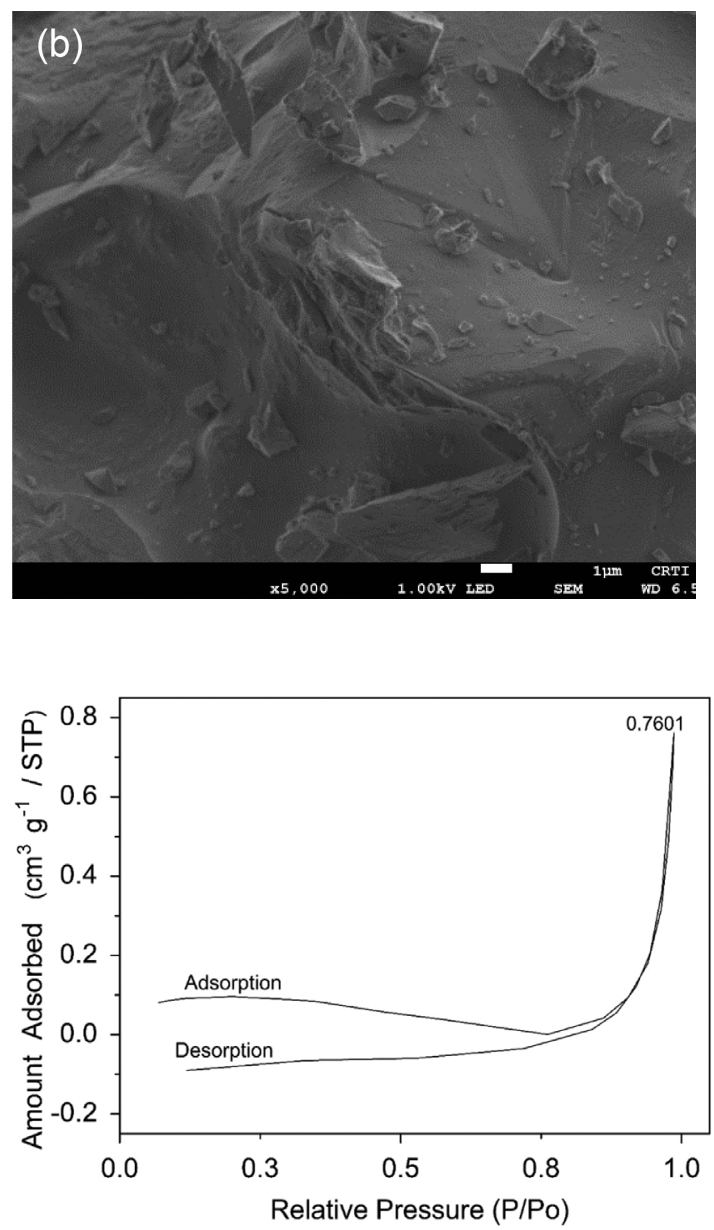

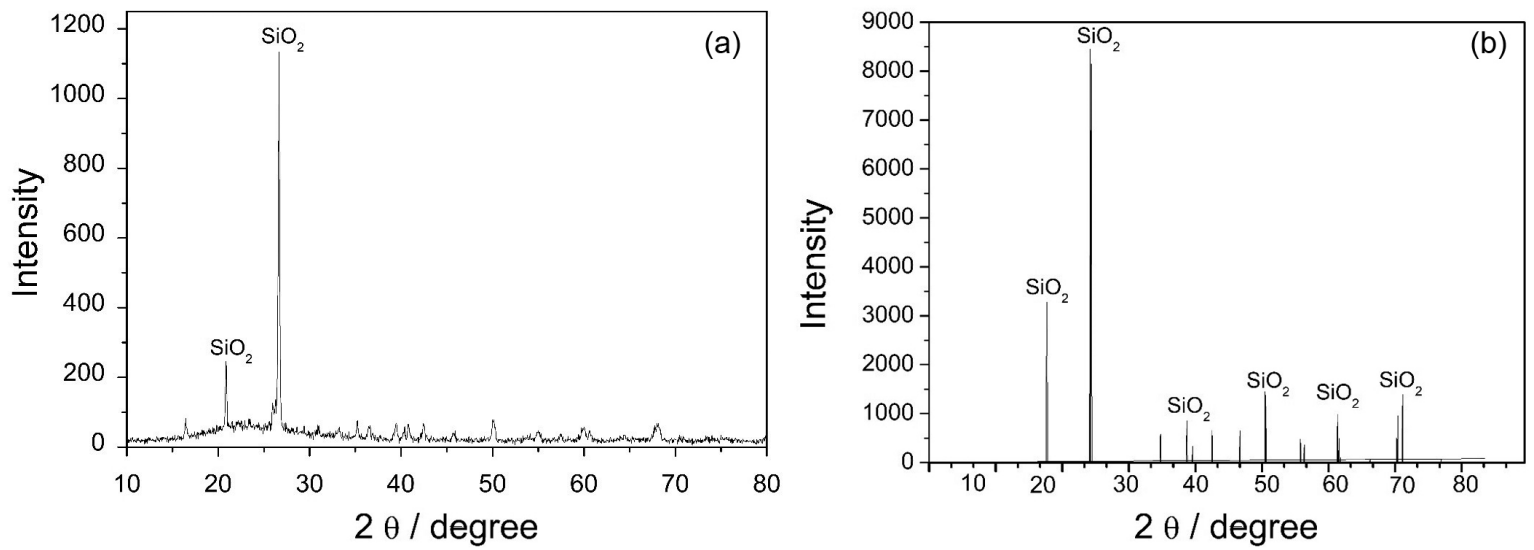

Figure 4. XRD diffractogram obtained for (a) the adsorbent and reference diffractogram for (b) quartz (adapted from Varela et al. ${ }^{55}$ ).

diffractogram for the quartz (Figure 4b), ${ }^{55}$ suggest there is quartz in crystalline phase.

\section{Adsorption study}

\section{Study on the $\mathrm{pH}_{\mathrm{pzc}}$}

The chemical structure and composition of an adsorbent surface are intrinsically linked to its adsorption capacity. ${ }^{56}$ The point of zero charge $\left(\mathrm{pH}_{\mathrm{PZC}}\right)$ indicates the $\mathrm{pH}$ value at which a solid has an electrically null load on its surface, that is, the number of positive charges is equal to the number of negative charges. Thus, if the $\mathrm{pH}$ of the solution is less than the $\mathrm{pH}_{\mathrm{PZC}}$ of the material, the surface will be positively charged and, conversely, if the $\mathrm{pH}$ of the solution is greater than the $\mathrm{pH}_{\mathrm{PZC}}$ of material, the surface will be negatively charged. ${ }^{57}$ Adsorption will occur more efficiently when the $\mathrm{pH}$ of the solution favors the contact and mass transfer of the adsorbate (fluid phase) to the adsorbent surface (solid phase).$^{58,59}$ Based on the relationship between the initial $\mathrm{pH}$ and the final $\mathrm{pH}$ of the solution, the $\mathrm{pH}_{\mathrm{PZC}}$ was calculated from the arithmetic mean of the points, in triplicate, for which the final $\mathrm{pH}$ is constant (Figure 5).

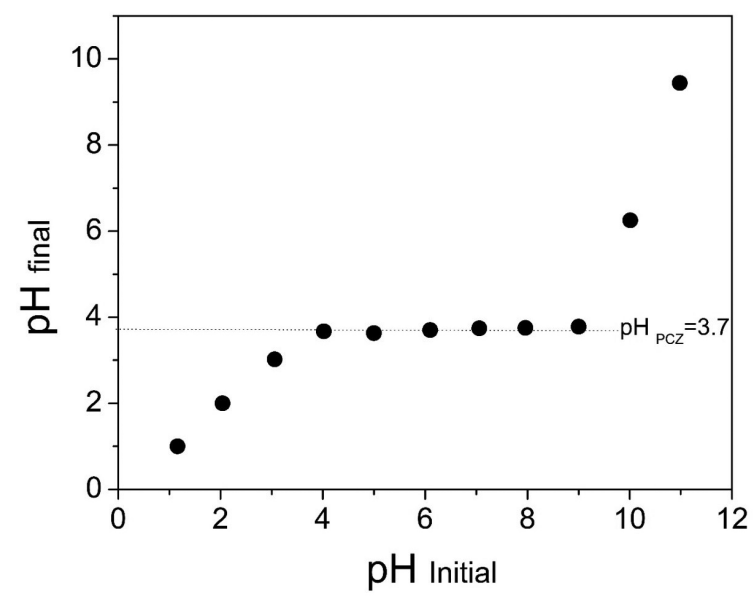

Figure 5. Graph of point of zero charge for adsorbent.
The value found to the $\mathrm{pH}_{\mathrm{PCZ}}$ parameter of the adsorbent was 3.7. Table 3 shows the $\mathrm{pH}_{\mathrm{PZC}}$ of different silicates found in the literature. The $\mathrm{pH}_{\mathrm{PCZ}}$ found in this study is similar to values reported in the literature. ${ }^{28,58,60-62}$

Table 3. Comparison of $\mathrm{pH}_{\mathrm{PZC}}$ obtained in this study with values reported in the literature

\begin{tabular}{lcc}
\hline Material & $\mathrm{pH}_{\text {PZC }}$ & Reference \\
\hline Silicas/Germany & 4.1 & Komulski $^{58}$ \\
$\mathrm{SiO}_{2} /$ Shokubai & $<4.0$ & Komulski $^{58}$ \\
Pyrogenic silicas & 4.3 & Komulski $^{58}$ \\
Pretreated kaolinite & 3.7 & ${\text { Zhuang and } \mathrm{Yu}^{60}}$ \\
$\mathrm{SiO}_{2}-\mathrm{K} / \mathrm{SiO}_{2}$-I & $3.8 / 4.5$ & Milonjic et al. $^{61}$ \\
Silicon insulators & 3.5 & Raiteri et al. ${ }^{62}$ \\
ALMS & 3.7 & this study
\end{tabular}

$\mathrm{pH}_{\mathrm{PZC}}$ : point of zero charge; ALMS: aluminosilicate.

\section{Effect of $\mathrm{pH}$ on the adsorption system}

The study of $\mathrm{pH}$ in the system is a main factor in the adsorption of dyes. The effect of $\mathrm{pH}$ on dye adsorption onto ALMS was analyzed over the $\mathrm{pH}$ range of 5-8 because reports in the literature indicate that $\mathrm{pH}<\mathrm{pH}_{\mathrm{PZC}}$ can cause the dealumination $\left(\mathrm{Al}_{3}^{+}\right)$of adsorbent material, ${ }^{27}$ reducing the ion exchange potential by half. ${ }^{59,62-67}$ Values of $\mathrm{pH}>8$ are inconsistent with the Beer-Lambert law and were neglected. Figure 6 shows that with increasing $\mathrm{pH}$, the adsorption capacity $(q)$ increases slightly. When the initial solution $\mathrm{pH}$ was increased from 5 to 8 , the adsorption increased from 0.149 to $0.162 \mathrm{mg} \mathrm{g}^{-1}$ for methylene blue and 0.216 to $0.271 \mathrm{mg} \mathrm{g}^{-1}$ for crystal violet. For both dyes, the highest adsorption capacity (q) was observed at $\mathrm{pH} 8$. Alkaline solutions provide an increase in negative groups on the surface of the adsorbent $\left(\mathrm{pH}>\mathrm{pH}_{\mathrm{PZC}}\right)^{43,66-68}$ promoting the interaction of the dyes crystal violet (Figure 7a) and methylene blue (Figure 7b) with the surface of the material. This increase in electrostatic attraction between 
the ALMS and the dyes is associated with a small degree of competition for $\mathrm{H}^{+}$ions or other metal ion substitution in alkaline solutions, providing negative surface charges, as described in the literature. . $^{10,29,43,66-68}$

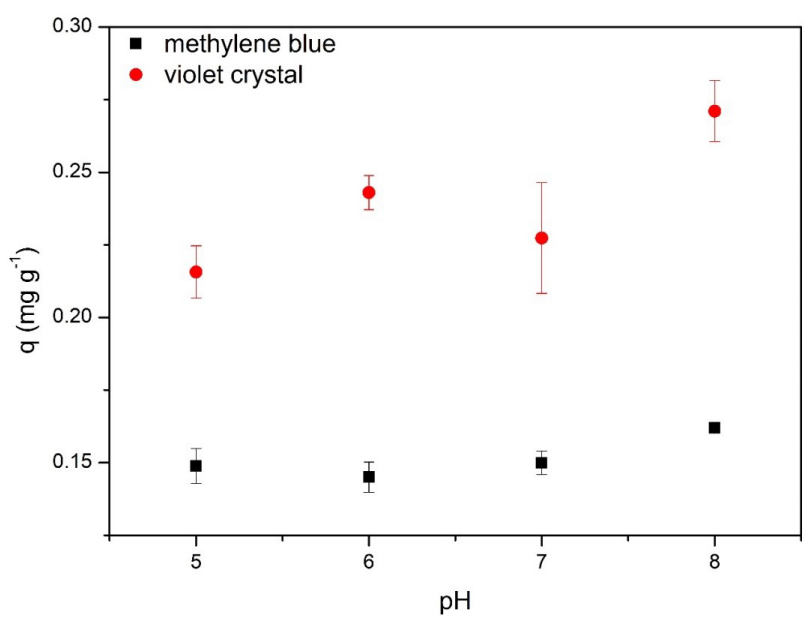

Figure 6. Effect of $\mathrm{pH}$ on the adsorption of methylene blue and crystal violet. Conditions: volume of dye solution $\left(\mathrm{V}_{\mathrm{SC}}\right)=25 \mathrm{~mL}$; mass $=100 \mathrm{mg}$; $\mathrm{T}=25^{\circ} \mathrm{C}$; time $=24 \mathrm{~h}$, [dyes] $=10 \mathrm{mg} \mathrm{L}^{-1}$.

\section{Mass effect}

Figure 8 shows the effect of adsorbent mass on the adsorption of the dyes methylene blue and crystal violet onto aluminosilicate. The results indicate that with a greater amount of adsorbent mass the percentage of dye removal in solution increased, up to a maximum of $1100 \mathrm{mg}$. At this mass, the system reached the equilibrium concentration since the process was predominantly influenced by the grain size and external surface area of the material (BET analysis). An increase in the adsorption capacity (q) as a function of mass has also been observed in other studies. ${ }^{30,50}$

\section{Adsorption kinetics}

The adsorption kinetics (Figure 9) was investigated to establish the optimal contact time between the adsorbent and the adsorbate (dyes), when equilibrium is reached by the system. ${ }^{69}$ In this experiment the temperature was varied: 298, 308 and $318 \mathrm{~K}$. The other parameters in the system were kept fixed. The temperature variation allowed the time at which the system reached equilibrium to be identified, verifying an influence on the adsorption process. ${ }^{29}$ The activation energy $\left(E_{a}\right)$ of the adsorption system was calculated (Table 4 ) along with the equilibrium concentration coefficient $\left(\mathrm{q}_{\mathrm{e}}\right)$ according to the contact time $\mathrm{e}^{70}$ at different temperatures (Figure 9). It was observed that the equilibrium occurred between 480 and $510 \mathrm{~min}$ for methylene blue (Figure 9a) and between 720 and $780 \mathrm{~min}$ for crystal violet (Figure 9b). A marked increase in the $\mathrm{q}_{\mathrm{e}}$ values and removal percentage was verified in the first moments of the adsorption process after which the adsorption process presented a lower rate of variation until the equilibrium was reached. The initial dye removal rate in the adsorption system was high, followed by a slower reaction over time until the system reached equilibrium.

The kinetic models were constructed and the pseudosecond-order model best described the adsorption of the dyes (Table 4), with coefficients that were close to or equal to 1 . Some studies involving the application of models to explain the kinetics of adsorption onto silicas and their derivatives reported in the literature provided correlations with the pseudo-second-order model. ${ }^{29,38,43,66-68}$

Table 5 shows the physical-chemical parameters obtained in the kinetics study of dyes. It was observed that the rate constant $\left(\mathrm{k}_{2}\right)$ in the pseudo-second-order model decreased with an increase in temperature, evidencing faster kinetics. ${ }^{43,66}$ In fact, it can be observed that the equilibrium time tends to decrease with an increase in temperature. It can be observed that the experimental and calculated adsorption capacity (q) have very similar values.

The activation energy was determined by equation 17 :

$\ln \mathrm{k}_{2}=\ln \mathrm{A}-\frac{\mathrm{Ea}}{\mathrm{R}} \times \frac{1}{\mathrm{~T}}$

where $\mathrm{k}_{2}$ is the kinetic rate constant of pseudo-first-order, $\mathrm{T}$ is the temperature in Kelvin, $\mathrm{R}=8.314 \mathrm{~J} \mathrm{~K}^{-1} \mathrm{~mol}^{-1}$ and $\mathrm{A}$ is the frequency factor or pre-exponential factor. The activation energy in the crystal violet adsorption process was higher than that for methylene blue, because an increase in temperature can strongly influence the

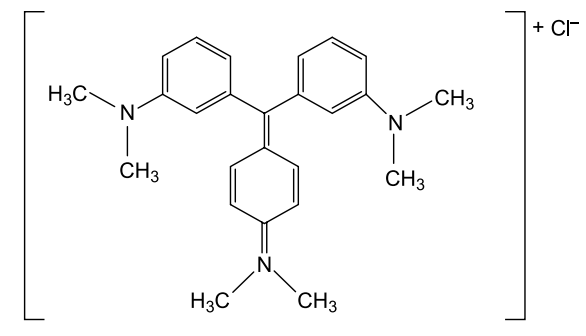

(a)<smiles>CN(C)c1ccc2nc3ccc(N(C)C)cc3nc2c1</smiles>

(b)

Figure 7. Chemical structure of dyes (a) crystal violet and (b) methylene blue. 


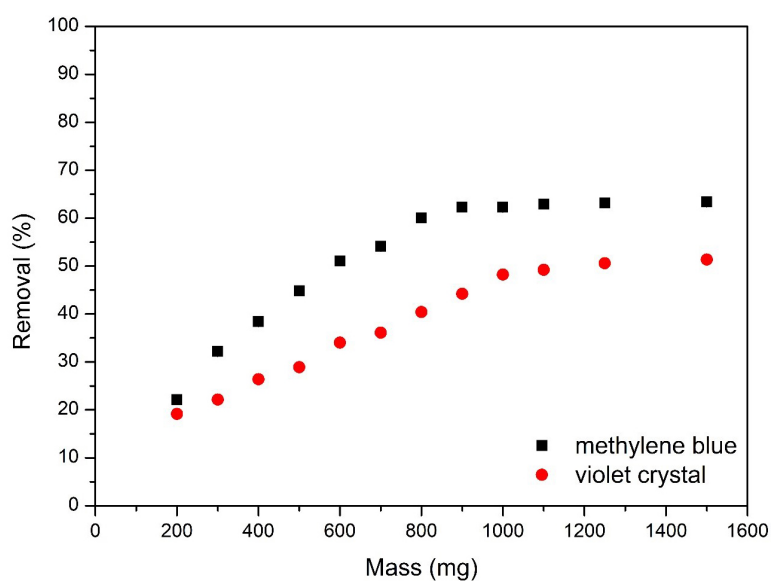

Figure 8. Effect of adsorbent mass on the adsorption efficiency. Conditions: $\mathrm{V}_{\mathrm{SC}}=25 \mathrm{~mL} ; \mathrm{pH}=8.0 ; \mathrm{T}=25^{\circ} \mathrm{C}$; time $=24 \mathrm{~h}$, [dyes $]=10 \mathrm{mg} \mathrm{L}^{-1}$.

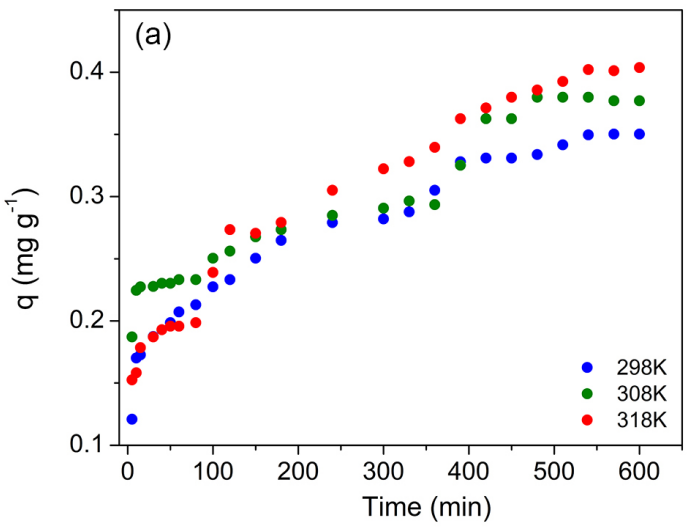

rate constant decrease. ${ }^{29,43}$ The $\mathrm{E}_{\mathrm{a}}$ value indicates if the adsorption process is physical or chemical, being physical for the range of 4 to $40 \mathrm{~kJ} \mathrm{~mol}^{-1}$ and chemical for 40 to $95 \mathrm{~kJ} \mathrm{~mol}^{-1} .^{71}$ Thus, the $\mathrm{E}_{\mathrm{a}}$ value obtained in this study suggests that a physical mechanism is involved in the adsorption (Table 5).

\section{Adsorption isotherms}

The adsorption isotherms at different temperatures of methylene blue and crystal violet are shown in Figure 10 and the parameters obtained are listed in Table 6.

The $\mathrm{q}_{\max }$ values obtained ranged from 0.35 to $0.52 \mathrm{mg} \mathrm{g}^{-1}$, indicating that the adsorbent has little affinity with the dyes. This low affinity can be explained by the fact that

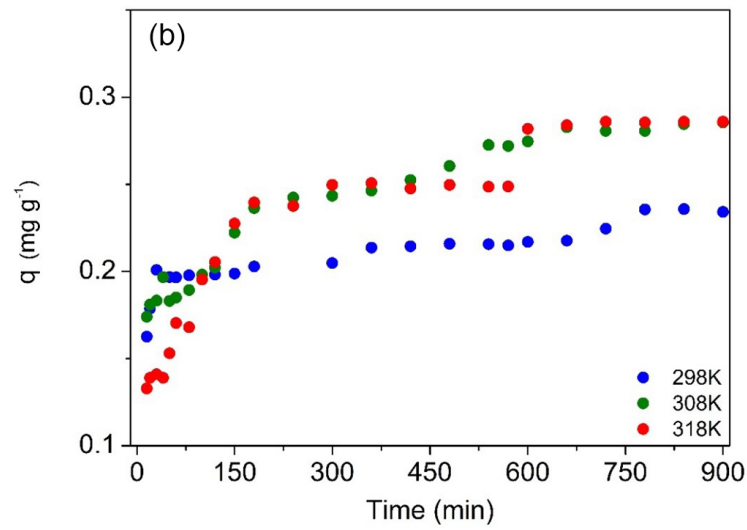

Figure 9. Kinetics results for the adsorption of dyes onto the adsorbent: (a) methylene blue and (b) crystal violet. Conditions: $\mathrm{V}_{\mathrm{SC}}=50 \mathrm{~mL} ; \mathrm{pH}=8.0$; mass $=1100 \mathrm{mg} ; \mathrm{T}=25^{\circ} \mathrm{C} ;$ time $=24 \mathrm{~h}$, [dyes] $=10 \mathrm{mg} \mathrm{L}^{-1}$.

Table 4. Adj. R-square for kinetic models of the dye adsorption onto the adsorbent

\begin{tabular}{lccccc}
\hline \multirow{2}{*}{ Dye } & \multicolumn{3}{c}{$\mathrm{R}^{2}$} & & \\
\cline { 2 - 6 } & Temperature / K & Pseudo-first-order & Pseudo-second-order & Elovich & Intraparticle diffusion \\
\hline \multirow{3}{*}{ Methylene blue } & 298 & 0.9328 & 0.9918 & 0.9546 & 0.7384 \\
& 308 & 0.7996 & 0.9811 & 0.8152 & 0.6407 \\
\hline \multirow{3}{*}{ Crystal violet } & 318 & 0.9544 & 0.9816 & 0.9045 & 0.8132 \\
& 298 & 0.7390 & 0.9912 & 0.7218 & 0.8257 \\
& 308 & 0.9333 & 0.9963 & 0.9516 & 0.8159 \\
\hline
\end{tabular}

$\mathrm{R}^{2}$ : adj. R-square.

Table 5. Physical-chemical parameters of the pseudo-second order model in the adsorption of methylene blue and crystal violet dyes

\begin{tabular}{lcccccc}
\hline Dye & Temperature / $\mathrm{K}$ & $\begin{array}{c}\text { Rate constant }\left(\mathrm{k}_{2}\right) / \\
\left(\mathrm{g} \mathrm{mg}^{-1} \mathrm{~min}^{-1}\right)\end{array}$ & $\begin{array}{c}\mathrm{q}_{\mathrm{e}} \text { (calculated)/ } \\
\left(\mathrm{mg} \mathrm{g}^{-1}\right)\end{array}$ & $\begin{array}{c}\mathrm{q}_{\mathrm{e}} \text { (experimental) / } \\
\left(\mathrm{mg} \mathrm{g}^{-1}\right)\end{array}$ & $\begin{array}{c}\text { Equilibration } \\
\text { time } / \mathrm{min}^{2}\end{array}$ & $\begin{array}{c}\text { Activation energy }\left(\mathrm{E}_{\mathrm{a}}\right) / \\
\left(\mathrm{kJ} \mathrm{mol}^{-1}\right)\end{array}$ \\
\hline \multirow{3}{*}{ Methylene blue } & 298 & $7.64 \times 10^{-2}$ & 0.36 & 0.35 & 510 & \\
& 308 & $6.15 \times 10^{-2}$ & 0.39 & 0.38 & 480 & 19.0 \\
\hline \multirow{3}{*}{ Crystal violet } & 318 & $4.69 \times 10^{-2}$ & 0.45 & 0.41 & 480 & \\
& 298 & $17.68 \times 10^{-2}$ & 0.24 & 0.24 & 780 & \\
& 308 & $12.28 \times 10^{-2}$ & 0.29 & 0.29 & 720 & 29.3 \\
\hline
\end{tabular}

$\mathrm{q}_{\mathrm{e}}$ : equilibrium adsorption capacity. 
Table 6. Parameters for methylene blue and crystal violet adsorption isotherms obtained for adsorbent at different temperatures

\begin{tabular}{|c|c|c|c|c|c|}
\hline Dye & Isotherm & Parameter & $298 \mathrm{~K}$ & $308 \mathrm{~K}$ & $318 \mathrm{~K}$ \\
\hline \multirow{15}{*}{ Methylene blue } & \multirow{4}{*}{ Langmuir } & $\mathrm{q}_{\max } /\left(\mathrm{mg} \mathrm{g}^{-1}\right)$ & 0.37 & 0.37 & 0.38 \\
\hline & & $\mathrm{K}_{\mathrm{L}} /\left(\mathrm{L} \mathrm{mg}^{-1}\right)$ & 0.54 & 2.89 & 0.87 \\
\hline & & $\mathrm{R}_{\mathrm{L}}$ & 0.11 & 0.02 & 0.07 \\
\hline & & $\mathrm{R}^{2}$ & 0.9921 & 0.9015 & 0.9835 \\
\hline & \multirow{4}{*}{ Freundlich } & $\mathrm{K}_{\mathrm{F}} /\left(\mathrm{L} \mathrm{g}^{-1}\right)$ & 0.12 & 0.23 & 0.17 \\
\hline & & $1 / \mathrm{n}$ & 0.48 & 0.26 & 0.33 \\
\hline & & $\mathrm{n}$ & 2.09 & 3.85 & 3.02 \\
\hline & & $\mathrm{R}^{2}$ & 0.9731 & 0.9897 & 0.8947 \\
\hline & \multirow{4}{*}{ Temkin } & $\mathrm{K}_{\mathrm{T}} /\left(\mathrm{L} \mathrm{g}^{-1}\right)$ & 7.08 & 69.93 & 8.97 \\
\hline & & $\mathrm{B}_{\mathrm{T}}$ & 0.07 & 0.06 & 0.08 \\
\hline & & $\mathrm{b} /\left(\mathrm{J} \mathrm{mol}^{-1}\right)$ & 35.4 & 42.7 & 33.0 \\
\hline & & $\mathrm{R}^{2}$ & 0.9941 & 0.9910 & 0.9706 \\
\hline & \multirow{3}{*}{ D-R } & B & $2.62 \times 10^{-6}$ & $4.00 \times 10^{-7}$ & $1.33 \times 10^{-4}$ \\
\hline & & $\mathrm{E} /\left(\mathrm{kJ} \mathrm{mol}^{-1}\right)$ & 436.9 & 1118.0 & 61.3 \\
\hline & & $\mathrm{R}^{2}$ & 0.9300 & 0.7843 & 0.9223 \\
\hline \multirow{15}{*}{ Crystal violet } & \multirow{4}{*}{ Langmuir } & $\mathrm{q}_{\max } /\left(\mathrm{mg} \mathrm{g}^{-1}\right)$ & 0.35 & 0.52 & 0.49 \\
\hline & & $\mathrm{K}_{\mathrm{L}} /\left(\mathrm{L} \mathrm{mg}^{-1}\right)$ & 0.60 & 0.11 & 0.19 \\
\hline & & $\mathrm{R}_{\mathrm{L}}$ & 0.10 & 0.38 & 0.26 \\
\hline & & $\mathrm{R}^{2}$ & 0.9978 & 0.9644 & 0.9844 \\
\hline & \multirow{4}{*}{ Freundlich } & $\mathrm{K}_{\mathrm{F}} /\left(\mathrm{L} \mathrm{g}^{-1}\right)$ & 0.11 & 0.06 & 0.09 \\
\hline & & $1 / \mathrm{n}$ & 0.49 & 0.63 & 0.58 \\
\hline & & $\mathrm{n}$ & 2.05 & 1.58 & 1.71 \\
\hline & & $\mathrm{R}^{2}$ & 0.9817 & 0.9790 & 0.9696 \\
\hline & \multirow{4}{*}{ Temkin } & $\mathrm{K}_{\mathrm{T}} /\left(\mathrm{L} \mathrm{g}^{-1}\right)$ & 10.7 & 2.49 & 1.98 \\
\hline & & $\mathrm{B}_{\mathrm{T}}$ & 0.06 & 0.08 & 0.10 \\
\hline & & $\mathrm{b} /\left(\mathrm{J} \mathrm{mol}^{-1}\right)$ & 41.3 & 32.0 & 26.4 \\
\hline & & $\mathrm{R}^{2}$ & 0.9667 & 0.9018 & 0.9859 \\
\hline & \multirow{3}{*}{ D-R } & B & $2.90 \times 10^{-6}$ & $1.38 \times 10^{-5}$ & $4.72 \times 10^{-4}$ \\
\hline & & $\mathrm{E} /\left(\mathrm{kJ} \mathrm{mol}{ }^{-1}\right)$ & 415.2 & 190.3 & 32.5 \\
\hline & & $\mathrm{R}^{2}$ & 0.9589 & 0.7933 & 0.8862 \\
\hline
\end{tabular}

$\mathrm{q}_{\max }:$ maximum adsorption capacity; $\mathrm{K}_{\mathrm{L}}$ : the Langmuir constant; $\mathrm{R}_{\mathrm{L}}$ : equilibrium Langmuir parameter; $\mathrm{R}^{2}$ : correlation coefficient; $\mathrm{K}_{\mathrm{F}}$ : Freundlich constant; $1 / \mathrm{n}$ : empirical parameter; $\mathrm{K}_{\mathrm{T}}$ : Temkin isotherm constant; $\mathrm{B}_{\mathrm{T}}=\mathrm{RT} / \mathrm{b}, \mathrm{b}$ is the Temkin constant related to the heat of sorption, $\mathrm{T}$ is the absolute temperature and $\mathrm{R}$ is the ideal gas constant; $\mathrm{B}$ : sorption energy constant; $\mathrm{E}$ : adsorption energy.

the material goes through a sintering processes, which can modify the active sites capable of promoting ion exchange and adsorption. ${ }^{30}$

Table 7 shows the maximum adsorption capacity of similar industrial and ceramic solid residues found in the literature. ${ }^{72-77}$

It was observed that the temperature has very little influence on the adsorption process (Figure 10) and the methylene blue adsorption process is less sensitive to the temperature effect than the adsorption of crystal violet onto the aluminosilicate. ${ }^{42}$ The application of a physical or chemical treatment may increase the adsorption capacity of the clays and ceramic residues. ${ }^{26,78}$
The Langmuir and Freundlich parameters $\left(\mathrm{K}_{\mathrm{L}}, \mathrm{n}\right.$, and $\mathrm{K}_{\mathrm{F}}$ ) are also of the same order of magnitude as those reported in the literature, according to Bentahar et al..$^{29}$ and Ong et al..$^{42}$ In this study, the maximum adsorption capacity calculated using the Langmuir isotherm is much closer to the experimental adsorption value and with this approach there was a good fit with the equilibrium data, with a high correlation coefficient $\left(\mathrm{R}^{2}\right)$. The values for the separation factor $\left(R_{L}\right)$ observed for the adsorption of the dyes onto ALMS indicated that the adsorption process is favorable. Another way to evaluate whether the adsorption process is favorable or not is to observe the $\mathrm{n}$ parameter obtained from the Freundlich model. The value for the $n$ parameter 
Table 7. Maximum adsorption capacity $\left(\mathrm{q}_{\max }\right)$ of the materials and ceramic residues found in the literature

\begin{tabular}{|c|c|c|c|}
\hline Adsorbent & $\mathrm{q}_{\max } /\left(\mathrm{mg} \mathrm{g}^{-1}\right)$ & Dye used & Reference \\
\hline Carbonized watermelon & 200.00 & MB & Jawad et al. ${ }^{15}$ \\
\hline Biomass & 50.60 & MB & Jawad et al. ${ }^{16}$ \\
\hline Carbon modified chitosan & 56.70 & MB & Jawad et al. ${ }^{22}$ \\
\hline Waste materials & 1.26 & $\mathrm{CV}$ & Mittal et al..$^{72}$ \\
\hline Gangue ceramic microbeads & 2.17 & MB & Zhou et al..$^{73}$ \\
\hline Glass wool & 2.24 & MB & Chakrabarti and Dutta ${ }^{74}$ \\
\hline Red mud & 2.49 & $\mathrm{CV}$ & Wang et al. ${ }^{75}$ \\
\hline Fly-ash & 1.20 & MB & Woolard et al. ${ }^{76}$ \\
\hline Fly-ash (SFA) & 1.47 & MB & Janos et al. ${ }^{77}$ \\
\hline Chrome sludge & 0.51 & MB & Sanghi and Verma ${ }^{78}$ \\
\hline
\end{tabular}

MB: methylene blue, CV: crystal violet.
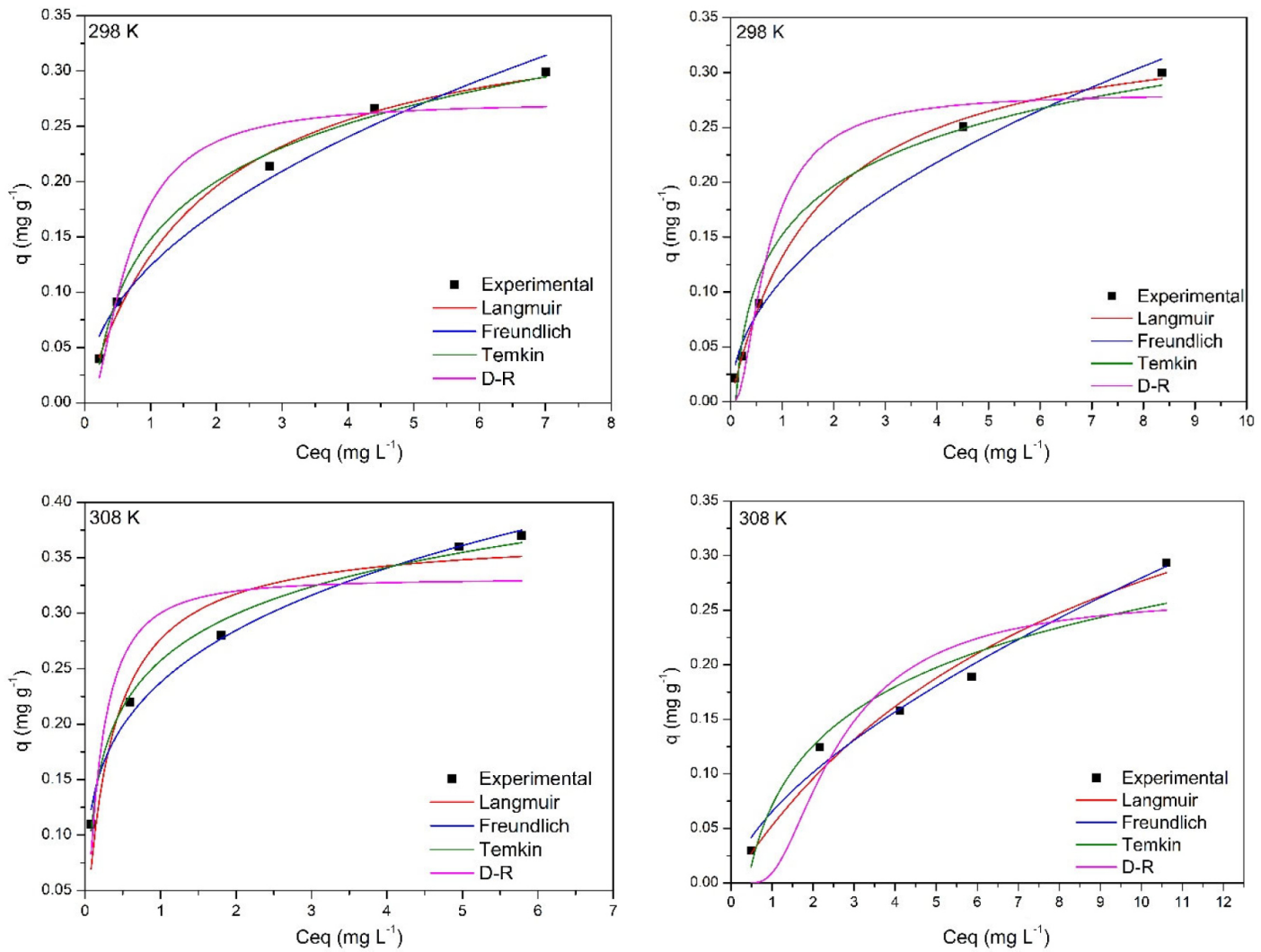

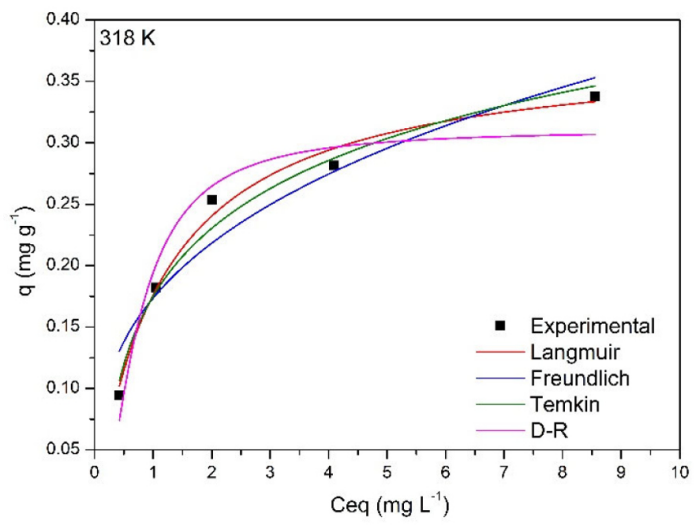

(a)

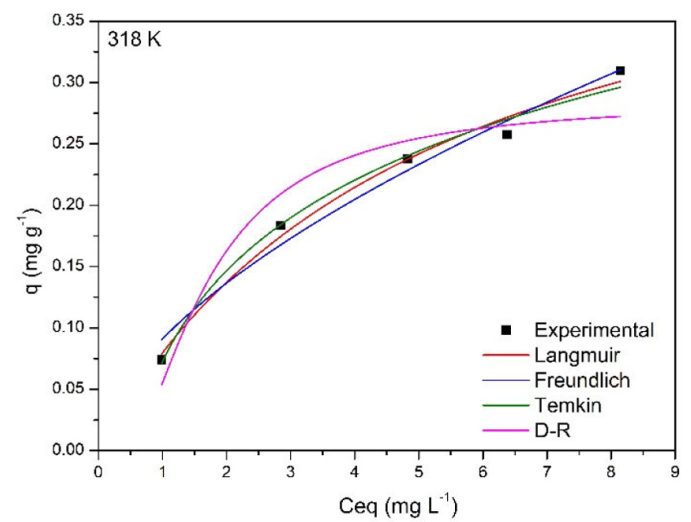

(b)

Figure 10. Adsorption isotherms obtained at different temperatures (a) methylene blue and (b) crystal violet. Conditions: $\mathrm{V}_{\mathrm{SC}}=50 \mathrm{~mL} ; \mathrm{pH}=8.0$; mass $=1100 \mathrm{mg} ; \mathrm{T}=25^{\circ} \mathrm{C} ;$ time $=24 \mathrm{~h}$. 
obtained in this study, regardless of the adsorbent, was $>1$, again suggesting that the process is favorable.

The constant $\beta$ obtained from the D-R isotherm allows an estimation of the adsorption energy (E) (see equation 13), which provides information on the adsorption mechanism. The values for the adsorption energy (E) of the dyes in ALMS were all lower than $8 \mathrm{~kJ} \mathrm{~mol}^{-1}$, suggesting a weak interaction and indicating that the dye adsorption onto ALMS occurs through a physical mechanism. ${ }^{29,78}$

\section{Thermodynamic parameters of the adsorption process}

Table 8 shows the thermodynamic parameters obtained for the dye adsorption onto ALMS. It can be observed that the dye removal by the adsorbent decreased with an increase in temperature, suggesting an exothermic adsorption process. ${ }^{43}$ On the other hand, in studies on the adsorption equilibrium and adsorption isotherms at different temperatures the $\mathrm{q}_{\max }$ values showed an insignificant increase at different temperatures. These small differences can be explained by considering the Gibbs energy of individual systems. ${ }^{4}$

The enthalpy values $\left(\Delta \mathrm{H}^{\circ}\right)$ associated with the dyes adsorption onto the adsorbent were found to be negative (Table 8), indicating an exothermic process ${ }^{43,69}$ and the entropy values $\left(\Delta S^{\circ}\right)$ were also negative, ${ }^{43,69}$ indicating that there is a decrease in the randomness at the solid-solution interface. ${ }^{29,79-82}$

The Gibbs energy values $\left(\Delta G^{o}\right)$ indicated that the adsorption process was not spontaneous and decreases with an increase in temperature. ${ }^{66,83}$ This suggests that the adsorption process is mainly influenced by the area of contact between the adsorbent and the adsorbate. This, in turn, is directly influenced by the grain size, the adsorbent mass and the degree of randomness of the system at the solid-solution interface. Some authors have reported positive Gibbs energy values $\left(\Delta \mathrm{G}^{\mathrm{o}}>0\right)$ for soils, clay minerals and their derivatives. ${ }^{82}$

Table 8. Thermodynamic parameters obtained for the adsorption of the dyes

\begin{tabular}{lcccc}
\hline Dye & $\begin{array}{c}\text { Temperature } / \\
\mathrm{K}\end{array}$ & $\begin{array}{c}\Delta \mathrm{H}^{\mathrm{o}} / \\
\left(\mathrm{kJ} \mathrm{mol}^{-1}\right)\end{array}$ & $\begin{array}{c}\Delta \mathrm{S}^{\mathrm{o}} / \\
\left(\mathrm{J} \mathrm{mol}^{-1} \mathrm{~K}^{-1}\right)\end{array}$ & $\begin{array}{c}\Delta \mathrm{G}^{\mathrm{o}} / \\
\left(\mathrm{kJ} \mathrm{mol}^{-1}\right)\end{array}$ \\
\hline Methylene & 298 & & & +7.5 \\
blue & 308 & -26.0 & -112.3 & +8.6 \\
& 318 & & & +9.7 \\
\hline \multirow{3}{*}{ Crystal violet } & 298 & & & +8.0 \\
& 308 & -16.1 & -81.0 & +8.8 \\
& 318 & & & +9.7 \\
\hline
\end{tabular}

$\Delta \mathrm{H}^{\circ}$ : enthalpy; $\Delta \mathrm{S}^{\mathrm{o}}$ : entropy; $\Delta \mathrm{G}^{\mathrm{o}}$ : Gibbs free energy.

The Gibbs free energy value provides information on the adsorption mechanism. The $\Delta \mathrm{G}^{\circ}$ values for physisorption are in the range of -20 to $0 \mathrm{~kJ} \mathrm{~mol}^{-1},{ }^{84}$ for chemisorption they are between -80 and $-400 \mathrm{~kJ} \mathrm{~mol}^{-1}$, and for an equilibrium between physisorption and chemisorption the range is -20 to $-80 \mathrm{~kJ} \mathrm{~mol}^{-1}$. 31,55 The Gibbs free energy values for the adsorption process (Table 8) were lower than $20 \mathrm{~kJ} \mathrm{~mol}^{-1}$, thus suggesting a physisorption process..$^{29,31,69,84-86}$

\section{Conclusions}

The adsorbent material had an $\mathrm{Si} / \mathrm{Al}$ ratio of $4.2(\mathrm{~m}: \mathrm{m})$, suggesting that it can be characterized as an acid adsorbent. It has a rough and striated surface with the presence of silica crystals (quartz), associated with partially-organized crystalline materials. The most efficient dye adsorption occurred at $\mathrm{pH} 8.0$. The adsorption kinetics was favored by an increase in temperature and lower activation energy, and the pseudo-second-order kinetic model provided the best fit. The adsorption process was found to be predominantly physical, exothermic, favorable and non-spontaneous.

\section{Acknowledgments}

We acknowledge FAPEG and CAPES for financial support, the Regional Center for Technological Development and Innovation (CRTI) for the SEM analysis, the Institute of Chemistry of the Federal University of Brasília for the diffractogram and BET analysis data, FURNAS Centrais Elétricas for chemical analysis and Enel for donating aluminosilicate material.

\section{References}

1. Konicki, W.; Helminiaki, A.; Arabczyk, W.; Mijwoska, E.; Chem. Eng. Res. Des. 2018, 129, 259.

2. Idris, A. M.; El-Zahhar, A. A.; Microchem. J. 2019, 146, 429.

3. Srinvasan, A.; Viraraghavan, T.; J. Environ. Manage. 2010, 91 , 1915.

4. Vasques, A. R.; de Souza, S. M. A. G. U.; Weissenberg, L.; de Souza, A. A. U.; Vale, J. A. B.; Eng. Sanit. Ambient. 2011, 16, 245.

5. Wang, C.; Zhang, Y.; Yu, L.; Zhang, Z.; Sun, H.; J. Hazard. Mater. 2013, 260, 851.

6. Liu, H.; Guo, W.; Li, Y.; He, S.; He, C.; J. Environ. Chem. Eng. 2018, 6, 59.

7. Saleh, T. A.; Gupta, V. K.; J. Colloid Interface Sci. 2012, 371, 101.

8. Aguiar, J. E.; Cecilia, J. A.; Tavares, P. A. S.; Azevedo, D. C. S.; Castellón, E. R.; Lucena, S. M. P.; Silva Jr., I. J.; Appl. Clay Sci. 2017, 135, 35.

9. Banat, I. M.; Nigam, P.; Armour, G.; Singh, D.; Marchant, R.; Mchale, A. P.; Mcmullan, G.; Bioresour. Technol. 2000, 72, 219. 
10. Yang, R.; Dawei, L.; Li, A.; Yang, H.; Appl. Clay Sci. 2018, 151, 20.

11. Mor, S.; Chhavi, K. M.; Sushil, K. K.; Ravindra, K.; Environ. Dev. Sustainable 2018, 20, 625.

12. Jawad, A. H.; Ismail, K.; Ishak, M. A. M.; Wilson, L. D.; Chin. J. Chem. Eng. 2019, 27, 1716.

13. Jawad, A. H.; Abdulhameed, A. S.; Energy Ecol. Environ. 2020, $5,456$.

14. Jawad, A. H.; Hum, N. N. M. F.; Abdulhameed, A. S.; Ishak, M. A. M.; Int. J. Environ. Anal. Chem. 2020, DOI: 10.1080/03067319.2020.1807529.

15. Jawad, A. H.; Razuana, R.; Appaturib, J. N.; Wilsonc, L. D.; Surf. Interface 2019, 16, 76.

16. Jawad, A. H.; Abdulhameed, A. S.; Mastulihttps, M. S.; J. Taibah Univ. Sci. 2020, 14, 305.

17. Chicinas, R. P.; Bedelean, H.; Stefan, R.; Mãicãneanu, A.; J. Mol. Struct. 2018, 1154, 187.

18. Jawad, A. H.; Abdulhameed, A. S.; Surf. Interface 2020, 18, 100422 .

19. Li, P.; Gao, B.; Li, A.; Yang, H.; Microporous Mesoporous Mater. 2017, 8714, 35.

20. Maucec, D.; Suligoj, A.; Ristik, A.; Drazic, G.; Pintar, A.; Tusar, N. N.; Catal. Today 2018, 30, 32.

21. Abbasi, M.; Habibi, M. M.; J. Taiwan Inst. Chem. Eng. 2016, 62,112 .

22. Jawad, A. H.; Abdulhameed, A. S.; Surip, S. N.; Sabar, S.; Int. J. Environ. Anal. Chem. 2020, DOI: 10.1080/03067319.2020.1807966.

23. Jawad, A. H.; Abdulhameed, A. S.; Mastuli, M. S.; J. Polym. Environ. 2020, 28, 1095.

24. Jawad, A. H.; Abdulhameed, A. S.; Abdallah, R.; Yaseen, Z. M.; Int. J. Biol. Macromol. 2020, 163, 756.

25. Santos, P. S.; Clays Science and Technology, vol. 1, $2^{\text {nd }}$ ed.; Edgard Blücher Publisher: São Paulo, Brazil, 1992.

26. Pinto, A. T.; Introdução ao Estudo dos Geopolímeros; Geopolymer System Inc., Universidade de Trás-os-Montes e Alto Douro: Vila Real, Portugal, 2006, available at http://www. geopolymer.com.br/PDF/introducao.pdf, accessed in April 2021.

27. Kausar, A.; Iqbal, M.; Javed, A.; Aftab, K.; Nazli, Z. H.; Bhatti, H. N.; Nouren, S.; J. Mol. Liq. 2018, 256, 395.

28. Moshoeshoe, M.; Nadiye-Tabbiruka, M. S.; Obuseng, V.; Am. J. Mater. Sci. 2017, 7, 196.

29. Bentahar, S.; Dbik, A.; Khomri, M.; Messaoudi, N.; Lacherai, A.; J. Environ. Chem. Eng. 2017, 5, 5921.

30. Dominguini, L.; Menegaro, D. A.; Miguel, T. F.; dal Bó, M.; Cerâmica 2014, 60, 218.

31. Bentahar, S.; Dbik, A.; El Khomri, M.; El Messaoudi, N.; Lacherai, A.; Groundwater Sustainable Dev. 2018, 6, 255.

32. ASTM D2149-13: Standard Test Method for Permittivity (Dielectric Constant) and Dissipation Factor of Solid Ceramic
Dielectrics at Frequencies to $10 \mathrm{MHz}$ and Temperatures to $500{ }^{\circ} \mathrm{C}$, ASTM International: West Conshohocken, PA, 2013.

33. ISO 29581-2: Cement Test Methods-Part 2 Chemical Analysis by X-Ray Fluorescence, ISO/TC 74, Cement and Lime, ISO: Vernier-Geneva, Switzerland, 2010.

34. Crini, G.; Peindy, H. N.; Gimber, T. F.; Robert, C.; Sep. Purif. Technol. 2007, 53, 97.

35. Kumar, P. S.; Ramalingam, S.; Kirupha, S. D.; Murugesan, A.; Vidhyadevi, T.; Sivanesan, S.; Chem. Eng. J. 2011, 167, 122.

36. Atkins, P.; Loretta, J.; Laverm, L.; Principles of Chemistry: Questioning Modern Life and the Environment, printed by Bookman Publisher: Porto Alegre, Brazil, 2001, ch. 13.

37. Altenor, S.; Ncibi, M. C.; Emmanuel, E.; Gaspard, S.; Biochem. Eng. J. 2012, 67, 35.

38. Zhang, J.; Dang, L.; Zhang, M.; Zhao, S.; Lu, Q.; Mater. Lett. 2017, 196, 194.

39. Peers, A.; J. Catal. 1965, 4, 499.

40. Rafati, L.; Ehrampoush, M. H.; Rafati, A. A.; Mokhtari, M.; Mahv, A. M.; J. Mol. Liq. 2016, 224, 832.

41. Ghosal, P. S.; Gupta, A. K.; J. Mol. Liq. 2017, 225, 137.

42. Ong, S.-T.; Tay, E.; Ha, S.-T.; Lee, W.; Keng, P. S.; Int. J. Phys. Sci. 2009, 4, 683.

43. Omer, O. S.; Hussein, M. A.; Hussein, B. H. M.; Mgaidi, A.; Arabian J. Chem. 2018, 11, 615.

44. Stanly, S.; Jelmy, E. J.; John, Q.; J. Polym. Environ. 2020, 28, 2433.

45. Langmüir, I.; J. Am. Chem. Soc. 1916, 38, 2221.

46. Saha, B.; Orvig, C.; Coord. Chem. Rev. 2010, 254, 2959.

47. Shukla, S. R.; Pai, R. S.; Shendarkar, A. D.; Sep. Purif. Technol. 2006, 47, 141.

48. Gilles, C. H.; Smith, D.; Huitson, A.; J. Colloid Interface Sci. 1974, 47, 755.

49. Gupta, V. K.; Ali, I.; Rio Saini, V. K.; J. Colloid Interface Sci. 2007, 315, 87.

50. Abidi, N.; Errais, E.; Duplay, J.; Berez, A.; Jrad, A.; Schafer, G.; Ghazi, M.; Semhi, K.; Trabelsi-ayadi, M.; J. Cleaner Prod. 2015, $86,432$.

51. Allen, S. J.; Gan, Q.; Matthews, R.; Johnson, P. A.; Bioresour. Technol. 2003, 88, 143.

52. Stoeckli, F.; Russ. Chem. Bull. 2001, 50, 2265.

53. Dubinin, M. M.; Zaverina, E. D.; Russ. Chem. Bull. 1955, 4, 531.

54. Bradley, S. A.; Broach, R. W.; Mezza, T. M.; Prabhakar, S.; Sinkler, W.; Zeolites in Industrial Separations and Catalysis, Zeolite Characterization; Kulprathipanja, S., ed.; Wiley Online Library: Des Plaines, USA, 2010, ch. 4.

55. Varela, M. L.; do Nascimento, R. M.; Martinelli, A. E.; Hotza, D.; Melo, D. M. A.; Melo, M. A. F.; Cerâmica 2005, 51, 388.

56. Youssef, A. M.; El-Nabarawy, T.; Samra, S. E.; Colloids Surf., A 2004, 235, 153. 
57. Hao, W.; Flynn, S. L.; Alessi, D. S.; Konhauser, K. O.; Chem. Geol. 2018, 493, 458.

58. Komulski, M.; Adv. Colloid Interface Sci. 2018, 251, 115.

59. Marçal, M. S.: Solketal Production for Glycerin Valorization; MSc. Dissertation, Higher Technical Institute, University of Lisboa, Lisboa, Portugal, 2015, available at https://fenix. tecnico.ulisboa.pt/downloadFile/1126295043835089, accessed in April 2021.

60. Zhuang, J.; Yu, G. R.; Chemosphere 2002, 49, 619.

61. Milonjic, S. K.; Cerovi, L. S.; Cokeša, D. J.; Zec, S.; J. Colloid Interface Sci. 2007, 309, 155.

62. Raiteri, R.; Margesin, B.; Grattarola, M.; Sens. Actuators, B 1998, 46, 126.

63. Senthilkumar, P.; Ramalingam, S.; Sathyaselvabala, V.; Kirupha, S. D.; Sivanesan, S.; Desalination 2011, 266, 63.

64. Pizzutti, I. R.; Schwerz, L.; Viaro, N. S. S.; Adaime, M. B.; Quim. Nova 1997, 20, 267.

65. Rahman, M. S.; Islam, M. R.; Chem. Eng. J. 2009, 149, 273.

66. Elmoubarki, R.; Mahjoubi, F. Z.; Tounsadi, H.; Moustadraf, J.; Water Res. 2015, 9, 16.

67. Hamza, W.; Dammak, N.; Hadjltaief, H. B.; Eloussaief, M.; Benzina, M.; Ecotoxicol. Environ. Saf. 2018, 163, 365.

68. Brião, G. V.; Jahn, S. L.; Foletto, E. L.; Dotto, G. L.; J. Colloid Interface Sci. 2017, 508, 313.

69. Almeida, C. A. P.; Debacher, N. A.; Downs, A. J.; Cottet, L.; Rio Melo, C. A. D.; J. Colloid Interface Sci. 2009, 332, 46.

70. Sheng, L.; Zhang, Y.; Tang, F.; Liu, S.; Microporous Mesoporous Mater. 2017, 257, 9.

71. Demarchi, C. A.; Debrassi, A.; Rodrigues, C. A.; Color. Technol. 2012, 128, 208.
72. Mittal, A.; Mittal, J.; Malviya, A.; Kaur, D.; Gupta, V. K.; J. Colloid Interface. Sci. 2010, 343, 463.

73. Zhou, L.; Zhou, H.; Hu, Y.; Yan, S.; Yang, J.; J. Environ. Manage. 2019, 234, 245.

74. Chakrabarti, S.; Dutta, B. K.; J. Colloid Interface Sci. 2005, 286, 807.

75. Wang, S.; Boyjoo, Y.; Choueib, A. A.; Chemosphere 2005, 60, 1401.

76. Woolard, C.; Forte, J.; Erasmus, C.; Appl. Geochem. 2002, 17, 1159.

77. Janos, P.; Buchtova, H.; Rýznarová, M.; Water Res. 2003, 37, 4938.

78. Sanghi, R.; Verma, P.; Color. Technol. 2013, 129, 85.

79. Lee, C. K.; Low, K. S.; Chow, S. W.; Environ. Technol. 1996, 17, 1023.

80. Liu, Y.; Liu, Y.-J.; Sep. Purif. Technol. 2008, 61, 229.

81. Ghosh, D.; Bhattacharyya, K. G.; Appl. Clay Sci. 2002, $20,295$.

82. Belbachir, I.; Makhoukhi, B.; J. Taiwan Inst. Chem. Eng. 2017, $75,105$.

83. El Messaoudi, N.; El Khomri, M.; Dbik, A.; Bentahar, S.; Lacherai, A.; J. Dispersion Sci. Technol. 2017, 38, 1168.

84. Sölener, M.; Tunali, S.; Özcan, A. S.; Özcan, A.; Gedikbey, T.; Desalination 2008, 223, 308.

85. Karak, T.; Paul, R. K.; Das, D. K.; Boruah, R. K.; Sonar, I.; Sci. World J. 2014, 216451.

86. Li, Q.; Yue, Q.-Y.; Su, Y.; Gao, B.-Y.; Sun, H.-J.; Chem. Eng. J. 2010, 158, 489.

Submitted: September 21, 2020

Published online: May 4, 2021 